\title{
Case Series and Review of the Literature
}

\section{Extra-Gonadal Teratomas in Atypical Sites in Neonates and Children - Our Experience and Review of the Literature}

\author{
Madhumita Mukhopadhyay ${ }^{1}$, Kartik Chandra Mandal', Chhanda Das ${ }^{3}$, Brati Mukhopadhyay $^{4}$, Biswanath \\ Mukhopadhyay ${ }^{5,6^{*}}$ and Pankaj Halder ${ }^{7}$
}

${ }^{1}$ Professor, Pathology, IPGME\&R, Kolkata, West Bengal, India

${ }^{2}$ Associate Professor, Pediatric Surgery, Dr. B C Roy Postgraduate Institute of Pediatric Sciences, Kolkata, West Bengal, India

${ }^{3}$ Assistant Professor, Pathology, IPGME\&R, Kolkata, West Bengal, India

${ }^{4}$ Resident, Anaesthesia, RIMS, Imphal, Manipur, India

${ }^{5}$ Professor and Senior Consultant Pediatric Surgeon, Apollo Gleneagles Hospitals, Kolkata, West Bengal, India

${ }^{6}$ Former Professor \& Head, Pediatric Surgery, NRS Medical College, Kolkata, West Bengal, India

${ }^{7}$ Associate Professor, Pediatric Surgery, RG Kar Medical College, Kolkata, West Bengal, India

\begin{tabular}{|c|c|}
\hline ARTICLE INFO & A B S T R A C T \\
\hline $\begin{array}{l}\text { Article history: } \\
\text { Received: } 14 \text { January, } 2021 \\
\text { Accepted: } 28 \text { January, } 2021 \\
\text { Published: } 12 \text { February, } 2021\end{array}$ & $\begin{array}{l}\text { Background: Extra-gonadal teratomas are rare tumors in Pediatric surgical practice. We studied the } \\
\text { teratomas of atypical sites attended in our tertiary care center. } \\
\text { Aim: Aim of the study was to find out the incidence of pediatric teratomas in atypical sites, clinical } \\
\text { presentation and histological variation. }\end{array}$ \\
\hline $\begin{array}{l}\text { Keywords: } \\
\text { Pediatric } \\
\text { retroperitoneum } \\
\text { neonates } \\
\text { teratoma } \\
\text { atypical sites } \\
\text { gastric } \\
\text { adrenal } \\
\text { pancreatic } \\
\text { the floor of the mouth } \\
\text { pulmonary } \\
\text { teratoid Wilms, } \\
\text { alpha-fetoprotein }(A F P)\end{array}$ & $\begin{array}{l}\text { Material and Methods: Over } 15 \text { years (January } 2005 \text { to December 2020), } 29 \text { cases of pediatric teratomas } \\
\text { in atypical sites were studied. These sites included neck (number-one), retroperitoneum (number-fourteen), } \\
\text { adrenal gland (number-two), renal (number-two), gastric(number-three), pancreas (number-one), } \\
\text { pulmonary (number-one), floor of the mouth(number-one), oral (number-two), abdominal wall (number- } \\
\text { one) and the mesentery (number-one). Patients were treated in the Department of Pediatric Surgery and } \\
\text { specimens were reviewed in the Department of Pathology. Age, sex, clinical presentation, investigations } \\
\text { (all patients had complete blood examination and alpha-fetoprotein) and imaging (USG of the local part and } \\
\text { CECT as guided by the organ of involvement). } \\
\text { Results: } 29 \text { pediatric teratomas in uncommon sites were reviewed. Out of } 14 \text { cases of retroperitoneal } \\
\text { teratoma, three were immature. Cervical teratoma in a neonate was mature. Three cases of gastric teratomas } \\
\text { were reported as mature. Two cases of adrenal teratomas also showed the histological features of mature } \\
\text { teratoma. Renal teratomas (two) were benign. One each of pulmonary teratoma, pancreas and floor of the } \\
\text { mouth were reported as mature. Two patients presented with oral teratoma were reported as mature } \\
\text { teratomas. One patient had teratoma arising from the abdominal wall and was resected completely (mature } \\
\text { teratoma). Teratoma arising from the mesentery also underwent complete resection. } \\
\text { Conclusion: A small percentage of Pediatric teratomas occur in atypical sites. In our series, retroperitoneal } \\
\text { tumors were predominant. Early surgical excision is the treatment of choice. Malignant change is known to } \\
\text { occur in Pediatric teratoma and the patients need long term follow-up. }\end{array}$ \\
\hline
\end{tabular}

\footnotetext{
${ }^{*}$ Correspondence to: Professor Dr. Biswanath Mukhopadhyay, M.S., M.Ch., F.R.C.S., F.A.M.S. (India), Professor and Senior Consultant Pediatric Surgeon, Apollo Gleneagles Hospitals, Kolkata and former Professor and Head, Pediatric Surgery, NRS Medical College, AD 144, Sector 1 Salt Lake, Kolkata, 700064, West Bengal, India; E-mail: mukhopadhyay_b@yahoo.in
} 


\section{Introduction}

The teratomas in gonads and sacrococcygeal area are relatively common neoplasms seen in pediatric surgical practice $[1,2]$. Teratomas in extragonadal sites are uncommon, varied in presentation and unpredictable biological behaviour [3]. The teratomas are embryonal tumors derived from at least 2 of 3 germ cell layers which differentiate into identifiable tissues and organs in ectopic locations [3]. Mature teratomas are known to undergo malignant change and they need long term follow-up [4]. The rare sites where teratomas are located are retroperitoneal space, mediastinum, pulmonary, stomach, the floor of mouth, tongue, kidney, thyroid, liver, heart, lung, fallopian tube, placenta [4]. We share our experience of teratomas arising in the retroperitoneum, neck, kidney, stomach, adrenal, pulmonary, the floor of the mouth, the pancreas, oral cavity, abdominal wall and the mesentery.

\section{Material and Methods}

The authors of the present study reviewed their experience on teratomas in extra-gonadal sites (retroperitoneum, neck, adrenal, renal, pulmonary, floor of the mouth, pancreas, oral cavity, abdominal wall, mesentery). Tables $1 \& 2$ show the age, sex, site, treatment, nature of the tumor and follow-up in the retroperitoneal area and other uncommon sites respectively. In 14 cases of retroperitoneal teratomas, 11 were reported as mature and 3 were immature as shown in (Table 1). All of them had baseline investigations $(\mathrm{CBC}$, urine microscopic examination, renal functions). Alpha-fetoprotein (AFP) was done in all cases and was raised in immature teratomas. After the surgical procedure, the specimens were sent to the Department Pathology. The study was carried out over a period 15 years from January 2005 to December 2010. 106 cases of pediatric teratoma were analysed in the Department of Pathology. Out of these, 29 cases were teratoma at atypical sites.

Table 1: Retroperitoneal teratomas.

\begin{tabular}{|l|l|l|l|l|l|}
\hline Age & Sex & Site & Treatment & Histology & Follow-up \\
\hline $6 \mathrm{~d}$ & M & Mid-abdomen & CE & Immature & Lost after 6M \\
\hline $7 \mathrm{y}$ & $\mathrm{M}$ & Whole abdomen & CE & Mature & Well after $10 \mathrm{y}$ \\
\hline $3 \mathrm{y}$ & $\mathrm{F}$ & Right lower abdomen & CE & Mature & Well after $5 \mathrm{y}$ \\
\hline $1 \mathrm{y}$ & $\mathrm{F}$ & Mid abdomen & CE & Mature & Mell after $10 \mathrm{y}$ \\
\hline $9 \mathrm{y}$ & $\mathrm{M}$ & Mid abdomen & CE & Immature & Well after $10 \mathrm{y}$ \\
\hline $7 \mathrm{~m}$ & $\mathrm{~F}$ & Lower abdomen & CE & Mature & Well after $1 \mathrm{y}$ \\
\hline $18 \mathrm{~m}$ & $\mathrm{~F}$ & Right lower abdomen & CE & Mature & Well after $11 \mathrm{y}$ \\
\hline $30 \mathrm{~m}$ & $\mathrm{~F}$ & Mid abdomen & CE & Mature & Well after $12 \mathrm{y}$ \\
\hline $3 \mathrm{y}$ & $\mathrm{F}$ & Left lower abdomen & CE & Mature & Well after $10 \mathrm{y}$ \\
\hline $7 \mathrm{y}$ & $\mathrm{M}$ & Mid abdomen & CE & Immature & Well after $10 \mathrm{y}$ \\
\hline $2 \mathrm{~m}$ & $\mathrm{~F}$ & Lower abdomen & CE & Mature & Died after $1 \mathrm{y}$ \\
\hline $11 \mathrm{y}$ & $\mathrm{F}$ & Mid abdomen & CE & Mature & Well after $4 \mathrm{y}$ \\
\hline $6 \mathrm{~m}$ & $\mathrm{M}$ & Right lower abdomen & CE & Mature & Well after $7 \mathrm{y}$ \\
\hline $12 \mathrm{~m}$ & $\mathrm{~F}$ & Mid abdomen & CE & & Well after $12 \mathrm{y}$ \\
\hline
\end{tabular}

d: days; y: year, M-Male; F-Female; CE: Complete Excision.

Table 2: Teratomas in other uncommon sites.

\begin{tabular}{|c|c|c|c|c|c|}
\hline Age & Sex & Site & Treatment & Histology & Follow-up \\
\hline $18 \mathrm{~m}$ & $\mathrm{M}$ & Stomach & $\mathrm{CE}$ & Mature & Well 5y \\
\hline $3 \mathrm{~m}$ & $\mathrm{~F}$ & Stomach & $\mathrm{CE}$ & Mature & Well 4y \\
\hline $24 \mathrm{~m}$ & $\mathrm{M}$ & Stomach & $\mathrm{CE}$ & Immature & Died after $3 \mathrm{~m}$ \\
\hline $2 \mathrm{~m}$ & $\mathrm{~F}$ & Kidney & $\mathrm{CE}$ & Mature & Well after $10 \mathrm{y}$ \\
\hline $7 \mathrm{~m}$ & $\mathrm{~F}$ & Kidney & $\mathrm{CE}$ & Mature & Well after $11 \mathrm{y}$ \\
\hline 7 y $5 \mathrm{~m}$ & $\mathrm{~F}$ & Adrenal & $\mathrm{CE}$ & Mature & Well after 6 y \\
\hline $1 \mathrm{y}$ & $\mathrm{M}$ & Adrenal & $\mathrm{CE}$ & Mature & Well after $5 y$ \\
\hline $4 y$ & $\mathrm{M}$ & Lung & $\mathrm{CE}$ & Mature & Lost to FU $2 y$ \\
\hline $10 \mathrm{~m}$ & $\mathrm{~F}$ & Pancreas tail & $\mathrm{CE}$ & Mature & Well after 8y \\
\hline $2 \mathrm{~d}$ & $\mathrm{M}$ & Neck & $\mathrm{CE}$ & Mature & Well after $10 \mathrm{y}$ \\
\hline $1 \mathrm{~d}$ & $\mathrm{~F}$ & Oral & $\mathrm{CE}$ & Mature & Well after $1 \mathrm{y}$ \\
\hline $12 \mathrm{~d}$ & $\mathrm{M}$ & Oral & $\mathrm{CE}$ & Mature & Lost to FU $3 \mathrm{~m}$ \\
\hline $4 \mathrm{~m}$ & $\mathrm{~F}$ & Floor mouth & $\mathrm{CE}$ & Mature & Well after $11 \mathrm{y}$ \\
\hline $1 \mathrm{y}$ & $\mathrm{M}$ & Abdominal wall & $\mathrm{CE}$ & Mature & Well after $6 \mathrm{~m}$ \\
\hline $3 \mathrm{~m}$ & $\mathrm{M}$ & Mesentery & $\mathrm{CE}$ & Mature & Well after $3 y$ \\
\hline
\end{tabular}

d: days; y: year, M-Male; F-Female; CE: Complete Excision 


\section{Results and Analysis}

Among 106 cases of pediatric teratomas, 29 cases were teratoma of atypical site. 14 were retroperitoneal teratoma, 3 cases were gastric teratoma, 2 cases were adrenal teratoma, 1 cervical teratoma, 1 pulmonary teratoma, 2 in the kidney, 1 occurred in the floor of the mouth, one in the pancreas, two from the oral cavity, one from the abdominal wall. The commonest rare site was retroperitoneum.

\section{Retroperitoneal Teratoma}

Out of 14 cases 9 were female and 5 were male. The youngest patient was 2-day-old male and the oldest patient was 7-year-old male. Most of the patients of retroperitoneal teratoma presented with gradually increasing swelling of the abdomen. The 2-day-old patient presented with absence of passing urine since birth. A 4-day-old male was diagnosed as a mesenteric cyst on ultrasound. 4-year-old female presented with left iliac mass. The specimens were partly cystic and partly solid in nature nodule or irregular in shape and maximum dimension was $15 \mathrm{~cm}$. On cut section, most of them had a visible bone, cartilage, hair, sebaceous material and greyish white neural tissue. Some had intestinal epithelium, bronchial epithelium, thyroid tissue and small glandular spaces lined by columnar epithelium. The specimen of 4-dayold female was mostly solid. The maximum diameter of the removed tumor was $10.5 \mathrm{~cm}$. On histopathological examination, immature neuroepithelial tissue and immature cartilage were found. It was an immature teratoma. Rest 11 cases were mature teratoma.

A 2-month-old male and another 1-month-old male came with epigastric swelling. All these patients had imaging (X-ray abdomen, ultrasonography and CECT abdomen) (Figure 1). Complete surgical resection the mass was done in all the cases (Figure 2) is showing an operative picture of one of our retroperitoneal teratomas. The histopathological examination revealed mature cartilage, neuroepithelial tissue and fatty tissue. In two patients of immature teratoma, follow-up AFP was within normal limit and no adjuvant therapy was given. One patient was lost to follow-up 6 months after surgery. One patient was doing well one year after surgery. Only one patient of immature retroperitoneal teratoma, operated at the age of 2 months, was recommended adjuvant chemotherapy but the parents refused chemotherapy. This baby died one year after surgical excision.

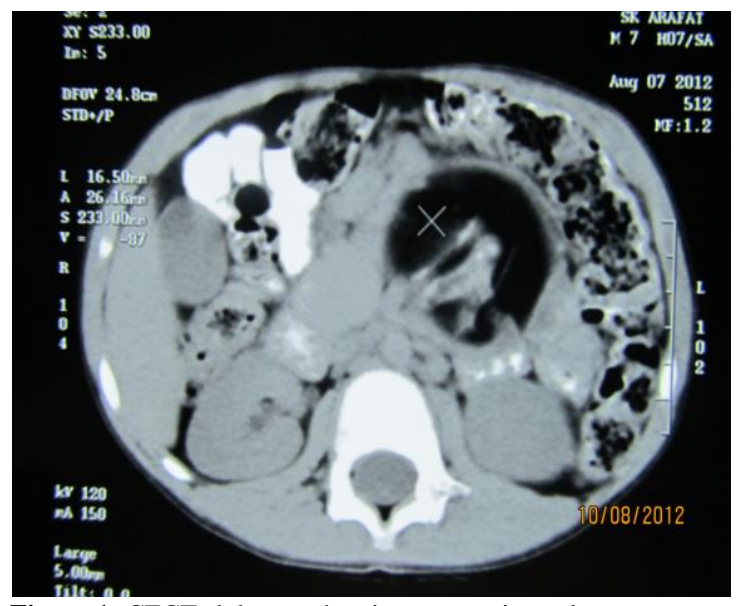

Figure 1: CECT abdomen showing retroperitoneal teratoma.

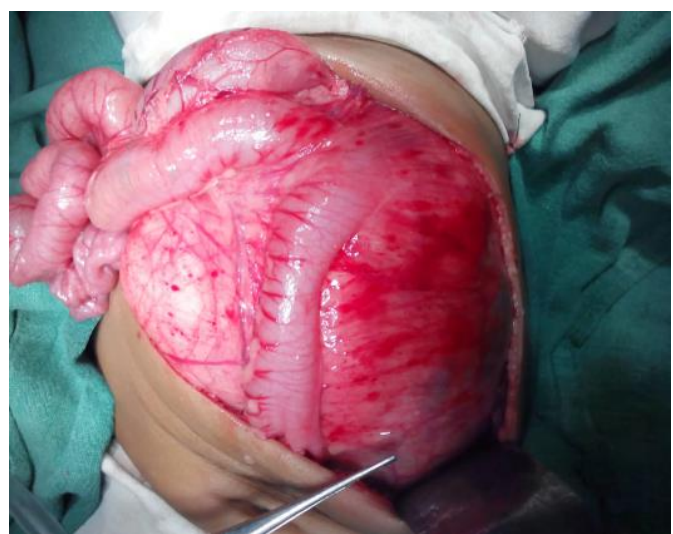

Figure 2: Retroperitoneal teratoma presented with lump and intestinal obstruction.

\section{Gastric Teratoma}

We treated three patients aged 18 months (male), 3 months (female) and 24 months (male). They presented with abdominal distension and vomiting. One patient had melena. An epigastric lump was palpable in all the cases. The patient with melena had severe anaemia. All patients required pre-operative stabilisation, baseline investigations, USG abdomen, gastroduodenoscopy, CECT abdomen. In two patients the mass was in the posterior wall and the other patient had a mass along the greater curvature. Complete excision of the mass was done along with partial gastrectomy. Postoperative recovery was uneventful. Two patients had mature teratoma and were doing well after 5 and 6 years respectively. Patient aged 3 months with immature teratoma was advised to come after 2 weeks of discharge but did not turn up for follow-up.

\section{Cervical Teratoma}

2- day-old baby presented with cervical swelling (Figure 3). Clinically it was a solid mass but at the base, some lesions were looking like cystic hygroma. The mass was bleeding from the surface of the tumor. Baseline investigations, AFP, ultrasonography of neck was done. The patient was stabilised and the swelling was excised as it was bleeding. The specimen was solid and hemorrhagic. The histopathological diagnosis was mature teratoma. This patient was last seen 10 years after operation and was well.

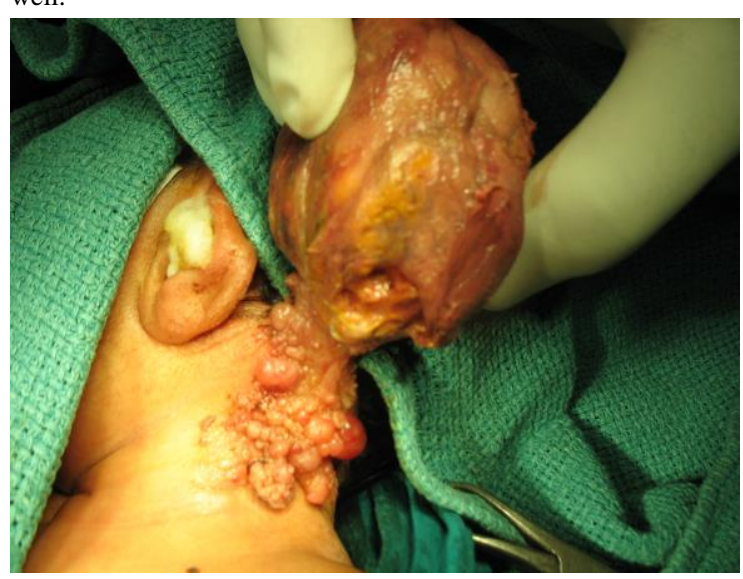

Figure 3: Neonatal cervical teratoma initially diagnosed as cystic hygroma. 


\section{Pulmonary Teratoma}

A 4-year-old boy came with respiratory distress with left side chest pain.

CECT showed a mass in the left lung (Figure 4). The mass was excised

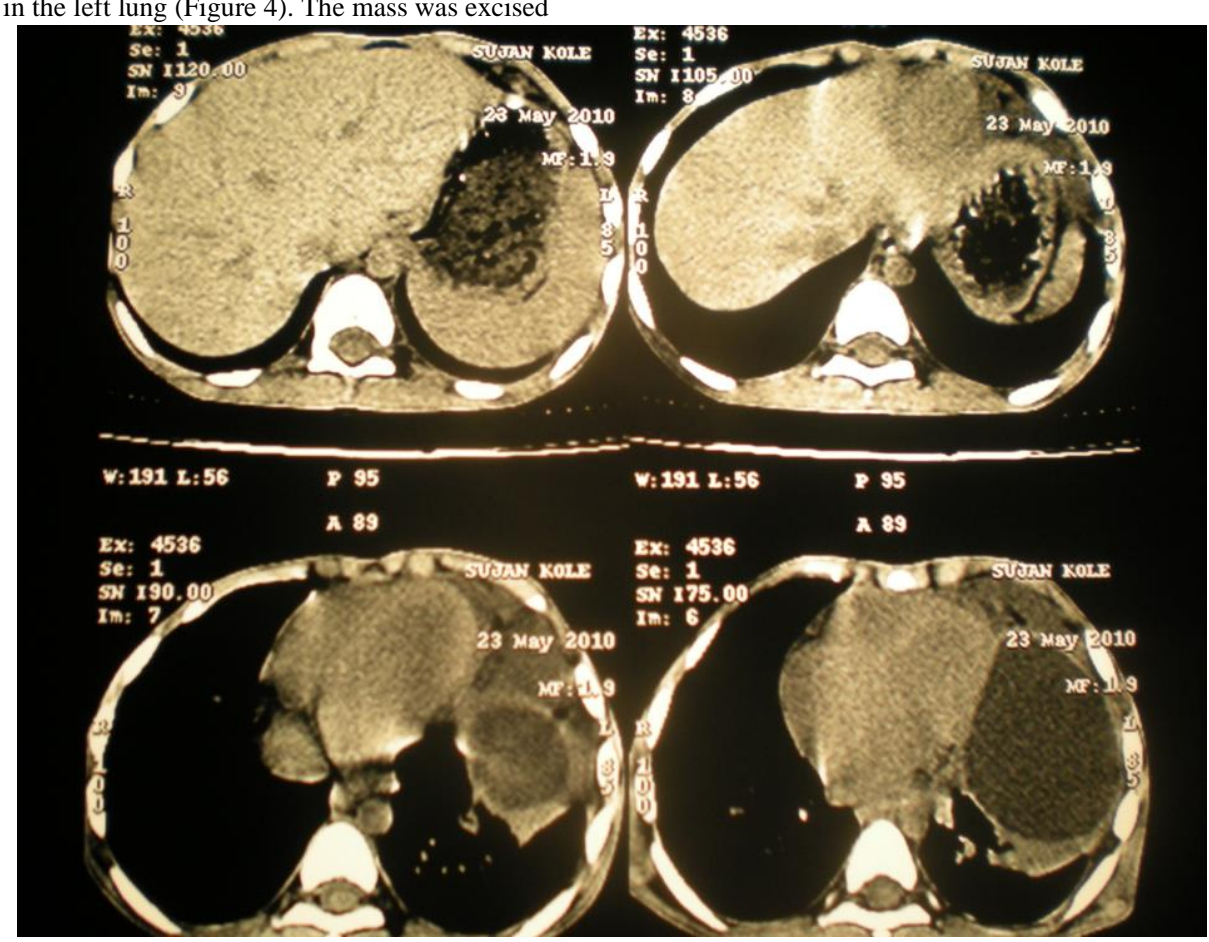

Figure 4: CECT lung showing pulmonary teratoma. completely and histopathology showed that the evidence of mature teratoma. This patient was well 2 years after surgery but lost to followup. 


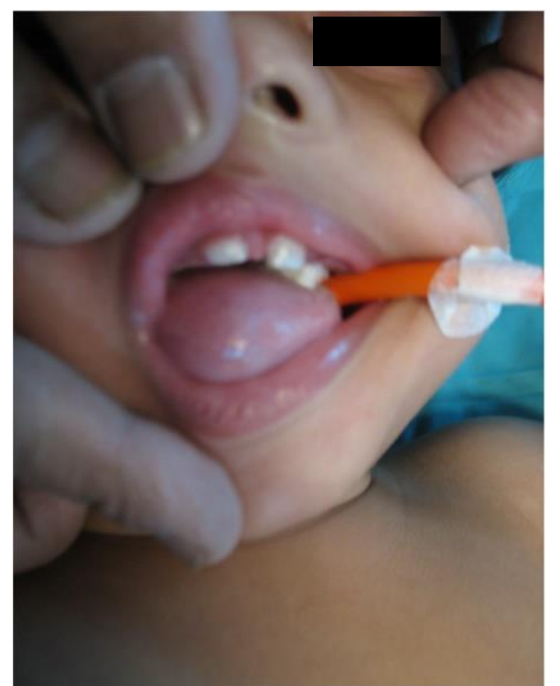

Figure 7: Teratoma arising from the floor of the mouth.

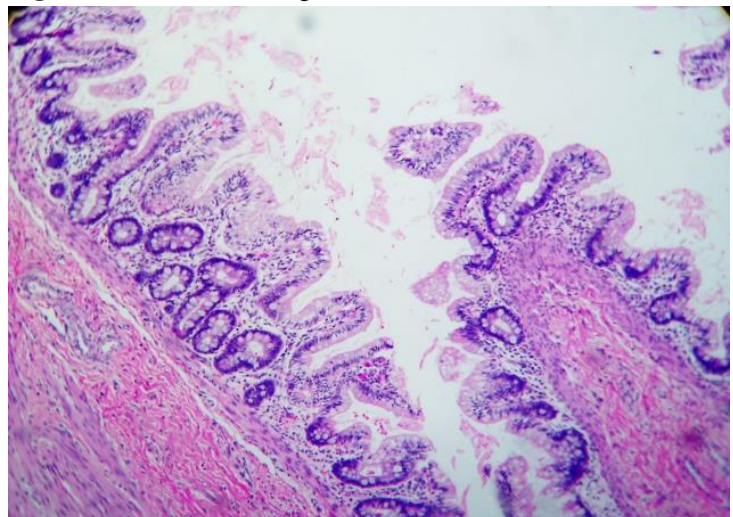

Figure 8: Mature teratoma showing intestinal glands (H \& E 400X).

\section{Pancreas Tail}

A 4-year- old male patient presented with a lump in the upper abdomen. USG and CECT abdomen revealed a mass arising from the pancreas (Figure 9). The tumor was arising from the tail of the pancreas and was completely removed (Figure 10). Histopathology was reported as mature teratoma. Doing well 8 years after the operation.

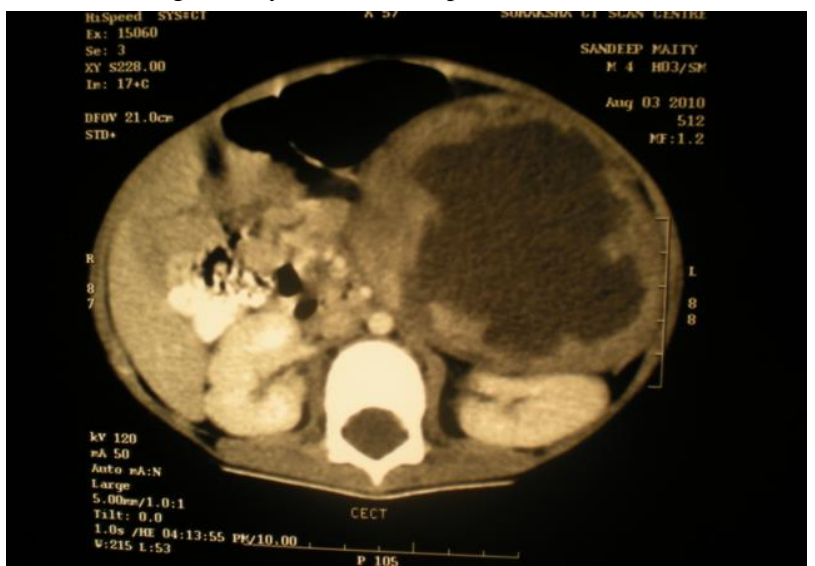

Figure 9: CECT abdomen showing tumor arising from the tail of the pancreas.

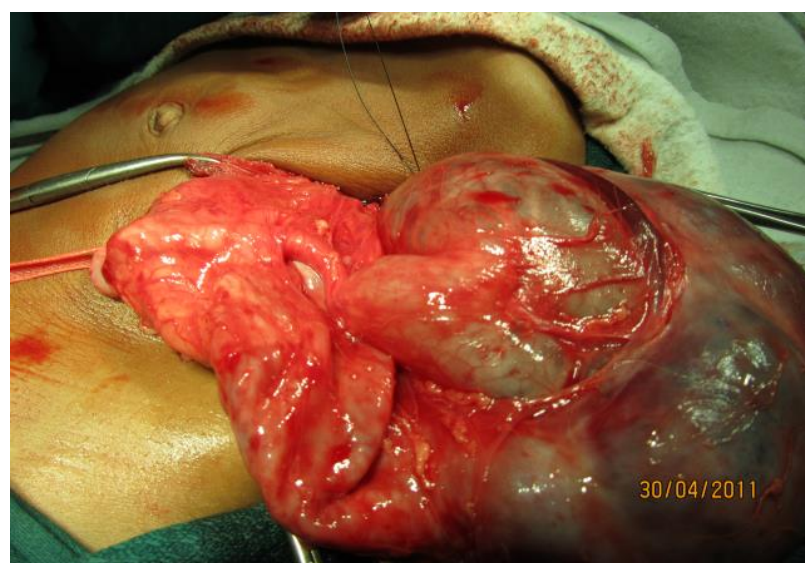

Figure 10: Operative picture of pancreatic teratoma arising from the tail.

\section{Renal Teratoma}

We encountered two cases of renal teratoma. They presented with an abdominal lump. Baseline investigations, X-Ray abdomen, USG abdomen and CECT abdomen were done. Because of the presence of calcification in the imaging AFP was done and was within normal limit. Nephrectomy was done and was reported as mature teratoma. Patients were doing well 10 and 11 years respectively after the operation.

\section{Abdominal Wall}

One year boy presented to us with the lump on the abdominal wall (Figure 11). Initially, the parents were not willing for surgical excision as the parents were from the poor socio-economic condition and were earning money by showing the baby. Later on, they were convinced that this tumor may cause a problem in day to day activities of the baby and agreed for surgery. Complete surgical excision was done and the tumor was mature. The patient was lost to follow-up after 6 months of surgery.

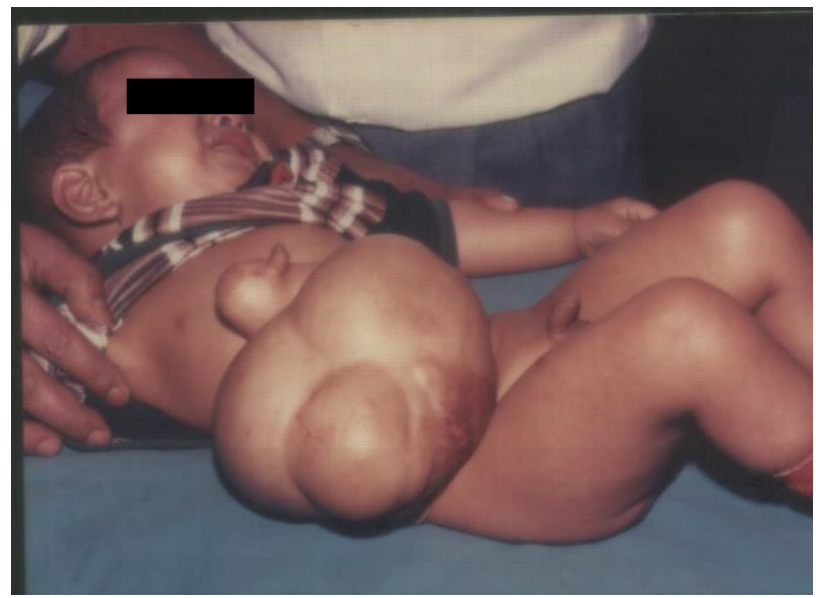

Figure 11: Abdominal wall teratoma.

\section{Oral Teratoma}

We treated two babies (one day and 12 days) of oral teratoma (Figure 12 of one day baby). The tumors were completely excised and were mature in nature. One patient was doing well 1 year after surgery but the other patient was lost to follow-up. 


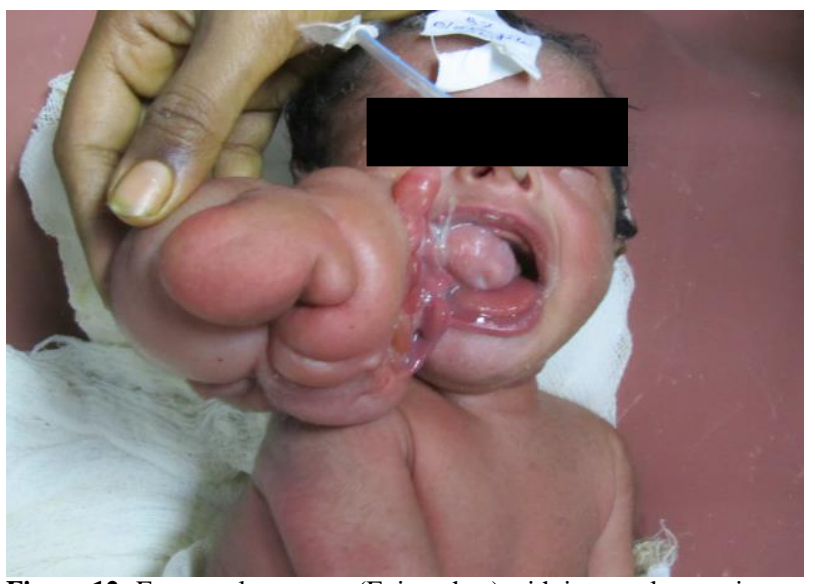

Figure 12: Extra oral teratoma (Epignathus) with intraoral extension.

\section{The Mesentery}

One infant aged 3 months presented with abdominal distension and vomiting. There was a lump in the mid-abdomen. Imaging showed features of small bowel obstruction. Laparotomy revealed a mass arising from the mesentery and was completely excised. Histopathology report was mature teratoma. The patient was doing well 3 years after surgery.

\section{Discussion}

Teratoma is defined as a tumor that is composed of tissues derived from more than one primitive germ cell layer and at least some of the tissues are foreign to the site in which it occurs. Retroperitoneal teratomas are the third most common tumors next to neuroblastoma and Wilms 'tumor in Pediatric age group [5]. Most of the retroperitoneal teratomas present with an abdominal lump [6]. USG abdomen, CECT abdomen is usually diagnostic. Aspiration cytology has been reported in some studies [7]. Alpha-fetoprotein (AFP) (preoperative and during postoperative followup) is done in all cases. Complete excision was possible in our cases. Three patients had immature teratoma but were followed up as the follow-up AFP was normal. Surgical excision is possible even in bilateral involvement and serum AFP is a reliable method of follow-up to detect recurrence [8]. Association of Down's syndrome and retroperitoneal teratoma has been reported but we did not see any patient with Down's syndrome in our series [9]. Gastric teratoma constitutes less than $1 \%$ of all germ cell tumors in the pediatric age group [10]. Most of the patients present with an abdominal lump, abdominal distension, vomiting, haematemesis or melena [11]. Complete surgical excision along with partial gastrectomy/ gastrectomy is curative in most of the cases [12]. Gastric teratoma including immature variety has an excellent prognosis after complete surgical excision. Adjuvant chemotherapy is recommended if there is rising AFP, and grade III immature teratoma. However, the role of chemotherapy in immature teratoma is not very clear because of limited experience and uncertain biological behaviour of these neoplasms [13].

Cervical teratomas are rare in neonates [14]. EXIT procedure (ex utero intrapartum treatment) has been described in cervical teratoma with fetal distress [14]. Neonatal cervical teratoma sometimes misdiagnosed as cystic hygroma as in one of our cases [15]. Complete excision is curative in most of the cases. Long term clinical follow up and happened biological tumor marker is mandatory to detect recurrence. Antenatal diagnosis has also been reported [16]. Pulmonary teratoma was first described by Mohr in 1939. Isolated case reports are available in the English literature [17]. It is believed that intrapulmonary teratomas are derived from the third endodermal pharyngeal pouch [17]. Respiratory distress and recurrent pulmonary infection are the usual modes of presentations. CECT chest (Figure 4) was confirmatory in our case. Complete excision of the tumor was possible in our patient. Histopathology was reported as mature. Pre-operative and postoperative AFP was normal.

Adrenal teratoma in Pediatric age group is extremely rare [18]. Adrenal teratoma may present with a lump or with the acute abdomen [2]. USG abdomen and CECT abdomen confirm the diagnosis. Complete surgical excision is most of the time curative. Both the cases in our series were followed up for more than 10 years and are doing well. Adrenocortical carcinoma should be considered as differential diagnosis and in suspected cases, hormonal assessment should be done. Teratoma arising from the pancreas is also extremely rare and was first described by Kerr [19-21]. Pancreatic teratomas usually present with an abdominal lump. MRI / CECT usually delineate the site and nature of the tumor. Except for AFP, other tumor markers like enolase, carcinoembryonic antigen, lack specificity and sensitivity. In our patient, the tumor was involving the tail of the pancreas and complete resection was possible. There was no exocrine and endocrine dysfunction during follow-up.

The incidence of renal teratoma is rare [22]. We reported a patient of renal teratoma with duplication of cecum and appendix in 2010 [23]. Mature teratomas must be differentiated from teratoid Wilms' tumor [23]. There are reports where patients with pure immature teratomas are treated by surgical excision alone with $85 \%$ event-free interval for more than 3 years [22]. Oropharyngeal teratoma constitutes only $2 \%$ of all pediatric teratomas [24]. Reported incidence in oral cavity is $1: 20,000$ to 1: 40,000 [25]. Epignathus are teratomas which contain fully developed organs and appendages. One of our oral teratomas fulfilled the criteria of epignathus (Figure 12). Early complete surgical excision is the treatment of choice. Mesenteric teratoma is extremely rare [26]. We encountered only one case in our series. Diagnosis is made after laparotomy in most of the cases. Complete surgical excision is curative in mature teratomas.
Abbreviations
USG: Ultrasonography
CECT: Contrast-Enhanced Computed Tomography
MRI: Magnetic Resonance Imaging
CBC: Complete Blood Count

\section{REFERENCES}

1. Mukhopadhyay B, Das C, Sengupta M, Saha AK, Mukhopadhyay M et al. (2018) An epidemiological review of sacrococcygeal teratoma over five years in a tertiary care hospital. Indian J Med Paediatr Oncol 39: 4-7. 
2. Baila NT, Liaqat N, Kanwal A, Hashim I, Saleem M et al. (2019) Adrenal teratoma: a rare retroperitoneal tumor. MOJ Clin Med Case Rep 9: 154-155.

3. Paradies G, Zullino F, Orofino A, Leggio S (2013) Mediastinal teratomas in children Case reports and review of the literature. Ann Ital Chir 84: 395-403. [Crossref]

4. Park CH, Jung MH, Ji YI (2015) Risk factors for malignant transformation of mature cystic teratoma. Obstet Gynaecol Sci 58: 475480. [Crossref]

5. Gatacombe HG, Assikis V, Kooby D (2004) Primary retroperitoneal teratoma: a review of literature. J Surg Oncol 86: 106-113. [Crossref]

6. Rattan KN, Yadav H, Srivastava D, Rattan A (2016) Childhood retroperitoneal teratomas: 5 years of experience in a tertiary-care hospital. Ann Pediat Surg 12: 158-161.

7. Das C, Sengupta M, Mukhopadhyay M, Saha AK (2014) Critical clinical appraisal of the role of computed tomography-guided minimally invasive aspiration cytology in evaluation of retroperitoneal masses. Indian J Med Paediatr Oncol 35: 60-65. [Crossref]

8. Chaudhury A, Misra S, Wakhlu A, Tandon RK, Wakhlu AK (2006) Retroperitoneal teratomas in children. Indian J Pediatr 73: 221-223. [Crossref]

9. Kobayashi T, Sakemi Y, Yamashita H (2014) Increased incidence of retroperitoneal teratomas and decreased incidence of sacrococcygeal teratomas in infants with Down syndrome. Pediatr Blood Cancer 61: 363-365. [Crossref]

10. Parvin S, Sengupta M, Mishra PK, Chatterjee U, Banerjee S et al. (2016) Gastric teratoma: A series of 7 cases. J Pediat Surg 51: 10721077. [Crossref]

11. Saleem M, Mirza B, Talat N, Sharif M (2017) Gastric teratoma: our 17year experience. J Pediatr Surg 53: 234-236. [Crossref]

12. Junhasavasdikul $\mathrm{T}$, Ruangwattanapaisam $\mathrm{N}$, Molagool $\mathrm{S}$, Lertudomphonwanit C, Sirachainan N et al. (2016) Immature gastric teratoma in an infant: a case report and review of the literatures. Clin Case Rep 4: 962-967. [Crossref]

13. Sharma A, Arora R, Gupta R, Dinda AK (2010) Immature gastric teratoma in an infant: Report of a case and review of the literature. Ind J Pathol Microbiol 53: 868-870. [Crossref]

14. Alexander VRC, Manjaly JG, Pepper CM, Ifeacho SN, Hewitt RJ et al. (2015) Head and neck teratomas in children-A series of 23 cases at
Great Ormond Street Hospital. Int J Pediatr Otorhinolaryngol 79: 2008-2014. [Crossref]

15. Muscatello L, Giudice M, Feltri M (2005) Malignant cervical teratoma: report of a case in a newborn. Eur Arch Otorhinolaryngol 262: 899904. [Crossref]

16. Elmasalme F, Giacomantonio M, Clarke KD, Othman E, Matbouh S (2000) Congenital Cervical Teratoma in Neonates: Case report and Review. Eur J Pediatr Surg 10: 252-257. [Crossref]

17. Asanos S, Hoshikawa Y, Yamane Y, Ikeda M, Wakasa H (2000) An intrapulmonary teratoma associated with bronchiectasis containing various kinds of primordium: a case report and review of literature. Virchows Arch 436: 384-388. [Crossref]

18. Ratkal JM, Shaik NJ, Salia D, Choukimath SM (2015) Rare primary retroperitoneal teratoma masquerading as adrenal incidentaloma. Afr $J$ Urol 21: 96-99.

19. Wang J, Yin Y, Cai Z, Shen C, Yin X et al. (2019) Pediatric pancreatic teratoma - A case report and literature review. Medicine (Baltimore) 98: e18001. [Crossref]

20. Lo Curto M, D' Angelo P, Cecchetto G, Klersy C, Dall'Igna P et al. (2007) Mature and immature teratomas: results of the first paediatric Italian study. Pediatr Surg Int 23: 315-322. [Crossref]

21. Kerr AA (1918) Cysts and pseudocysts of the pancreas - with report of cases. Surg Gynecol Obstet 27: 40-44.

22. Chu H, Deng QF, Liu X, Peng B, Can YS (2018) Kidney teratoma: A case report and literature review. Urol Case Rep 20: 83-84. [Crossref]

23. Mukhopadhyay M, Shukla RM, Mondal KC, Mukhopadhyay B (2010) Renal teratoma with duplication of cecum and appendix. J Pediatr Surg 45: 255-258. [Crossref]

24. Kolekar SS, Chincholi T, Nangare N, Patankar R (2016) Oral teratoma. Int J Appl Basic Med Res 6: 54-56. [Crossref]

25. Azizkhan RG, Haase GM, Applebaum H, Dillon PW, Coran AG et al. (1995) Diagnosis, management, and outcome of cervicofacial teratomas in neonates: A Children Cancer Group study. J Pediatric Sure 30: 312-316. [Crossref]

26. Alwakid IH, Madni M, Gupta RK, Seada LS, Alfayez AA et al. (2017) Giant mesenteric teratoma in a 6 month old. J Pediatr Surg Case Rep 27: 56-60. 